Escobar, Francisco J. (2020): Valente en clave musical de Sotelo: Fragmentos inéditos para la ópera Bruno o el Teatro de la Memoria (con ecos de Morente). Cultura, Lenguaje y Representación, Vol. XXIV, 25-34

ISSN $1697-7750 \cdot$ e-ISSN 2340-4981

DOI: http://dx.doi.org/10.6035/clr.2020.24.2

\title{
Valente en clave musical de Sotelo: Fragmentos inéditos para la ópera Bruno o el Teatro de la Memoria (con ecos de Morente)
}

\author{
Valente in Sotelo's Musical Key: Unpublished Fragments for the Bruno o el
} Teatro de la Memoria (with Echoes from Morente)

FRANCISCO J. ESCOBAR

UNIVERSIDAD DE SEVILLA

Artículo recibido el / Article received: 2020-03-28

Artículo aceptado el / Article accepted: 2020-05-26

RESUM: El presente artículo ofrece un estudio circunscrito a la ópera Bruno o el Teatro de la Memoria en un trabajo conjunto, aunque inconcluso, realizado por el compositor madrileño Mauricio Sotelo y el poeta orensano José Ángel Valente. Para ello, se implementa una pluralidad metodológica con planteamientos epistemológicos procedentes del comparatismo, los estudios culturales y el análisis histórico-filológico. Además, se aplican conocimientos y categorías conceptuales adscritos a la crítica textual, así como de la filologia d'autore o génétique des textes a la hora de editar los estadios redaccionales de los fragmentos de la ópera y varias cartas con documentos que contextualizan el proceso de composición. En lo que atañe a los resultados, destaca principalmente el estudio analítico y edición de tales textos con noticias desconocidas. Entre estos datos, a modo de conclusión, cabe poner de relieve la pervivencia y notoriedad del pensamiento humanístico de Giordano Bruno en la génesis de la ópera y sus implicaciones creativas tanto en Sotelo como en Valente. Por último, mención especial merece, a efectos de performatividad y práctica escénica, la figura de Enrique Morente, sobre todo por la identificación simbólica entre el cantaor granadino y la figura del humanista napolitano en calidad de personaje de la ópera.

Paraules clau: Giordano Bruno; Mauricio Sotelo; José Ángel Valente; Enrique Morente; Bruno o el Teatro de la Memoria; Fragmentos de un libro futuro; ópera; flamenco.

ABSTRACT: This article offers a study dedicated to the opera Bruno o el Teatro de la Memoria in a joint, although not finished, work carried out by the composer from Madrid Mauricio Sotelo and the orensian poet José Ángel Valente. For this purpose, a methodological plurality is implemented with epistemological approaches from Comparatism, Cultural Studies and Historical-philological Analysis. In addition, knowledge and conceptual categories attached to textual criticism, as well as the filologia d'autore or génétique des textes are applied when editing the editorial stages of the fragments of the opera and various letters 
with documents that contextualize the process of composition. Among the results, it is worth highlighting especially the analytical study and editing of such texts with unknown news. Among these data, by way of conclusion, we must underline the survival and notoriety of Giordano Bruno's humanistic thought in the genesis of the opera and its creative implications in both Sotelo and Valente. Finally, for the purposes of performance and stage practice, the figure of Enrique Morente deserves special mention, especially for the symbolic identification between the Grenadian cantaor and the figure of the Neapolitan humanist as an opera character.

Key words: Giordano Bruno; Mauricio Sotelo; José Ángel Valente; Enrique Morente; Bruno o el Teatro de la Memoria; Fragmentos de un libro futuro; Opera; Flamenco Music.

\section{A MODO DE INTRODUCCIÓN}

Oscuro es como la noche el canto.

(Valente)

El interés de José Ángel Valente (1929-2000) por la música contemporánea constituyó un estímulo que le llevó a trabajar, desde la década de los noventa hasta el año de su fallecimiento, con el compositor madrileño Mauricio Sotelo (1961-) ${ }^{1}$. En este sentido, a diferencia de su lectura interpretativa de Schönberg y Berg ${ }^{2}$, el poeta orensano no tuvo en cuenta un libreto como fuente principal, sino que él mismo participó en la responsabilidad textual de la ópera Bruno o el Teatro de la Memoria (1994-), inédita hasta la fecha. En cambio, al igual que sucede con los otros compositores, Valente sí tuvo como referente la música de Sotelo a la hora de componer los textos que vamos a analizar en las páginas siguientes.

Pues bien, dos son los proyectos esenciales en los que colaboraron al unísono Valente y Sotelo, experimentando ambos artífices una influencia recíproca desde sus respectivos campos de trabajo. La primera empresa conjunta se habrá de materializar en la mencionada ópera Bruno o el Teatro de la Memoria, tomando como eje vertebrador al humanista Giordano Bruno y su arte de la memoria ${ }^{3}$, e incluso otros conceptos destacados

\footnotetext{
${ }^{1}$ Sobre el estado de la cuestión circunscrito a este compositor: Pérez Castillo (1999-2001), Pérez Frutos (2007-2008), el monográfico El canon (VV. AA., 2011) dedicado a Sotelo y con calas a propósito de Morente, así como Ordóñez Eslava (2011: 103-266; 2019a); respecto a la página web del compositor, con datos de interés para el presente objeto de estudio: http://www.mauriciosotelo.com/Home.html. Quisiera agradecer, en fin, tanto a Sotelo como a Morente la ejemplar dedicación de ambos a la intersección de códigos entre música contemporánea y flamenco. Tal gratitud incluye el aporte de claves analíticas para esta investigación, con énfasis en mis conversaciones con el maestro granadino sobre las fronteras entre el discurso musical y el literario, con el compositor madrileño y Valente al fondo. Junto a ellos, agradezco igualmente, en lo que se refiere no solo a directrices y labor de campo en calidad de informantes sino también al acceso a los fragmentos que edito, a los músicos Arcángel, Esperanza Fernández, Carmen Linares, Marina Heredia, Soleá Morente, Rosario la Tremendita, Rafael de Utrera, Paco Cruzado, Tomatito, Juan M. Jiménez y Antonio Moreno, y, claro está, a los reconocidos expertos en la obra de Valente y amigos personales suyos: Ramón de Torres, Fernando García Lara, Andrés Sánchez Robayna y Nuria Fernández Quesada; por último, conste siempre mi agradecimiento a Coral Valente.

${ }^{2}$ Escobar (2012c, 2017).

${ }^{3}$ Baste recordar De Imaginum signorum et idearum compositione (Saiber, 2005), con huellas en la obra homónima I y II de Sotelo. Este compositor, quien para una renovada versión de la ópera está contando en
} 
como la «asinidad positiva», al hilo de la «escucha» receptiva frente a la negativa, con metamorfosis apuleyana del ser humano en asno de fondo. Valente recuerda, además, del insigne humanista el intrínseco vínculo entre las artes, que toma como estandarte tanto en su obra ensayística como en la poética, en la medida en que una misma «materia» se erige como el movimiento matriz que unifica las distintas disciplinas estéticas. Desde este complejo prisma compositivo, Valente, en su conocida conversación con Tàpies ${ }^{4}$, alude a una colaboración en el plano textual en la ópera planteada con Sotelo, sin especificar en qué va a consistir su aportación.

Con el tiempo, ambos artistas habrán de colaborar en un segundo proyecto interdisciplinar que Valente no llegaría a ver concluido y que el músico le acabaría dedicando al trasluz de un título sugerido por una obra suya homónima, Si después de morir ... (1999-2000), en diálogo con «Elegía: Fragmento» (1994) del poeta orensano y que fue merecedora del Premio Reina Sofía de Composición Musical del año 20005. Me refiero a Si después de morir ... In memoriam José Ángel Valente, con edición impresa para Universal Edition en 2003, que atesora la música de dicho compositor en armonía con la lectura grabada antes de su fallecimiento por parte de Valente de varios poemas que conforman un ciclo unitario adscrito a Fragmentos de un libro futuro.

Figura 1. Si después de morir...: inicio de la obra (Sotelo, 2003c: 1)

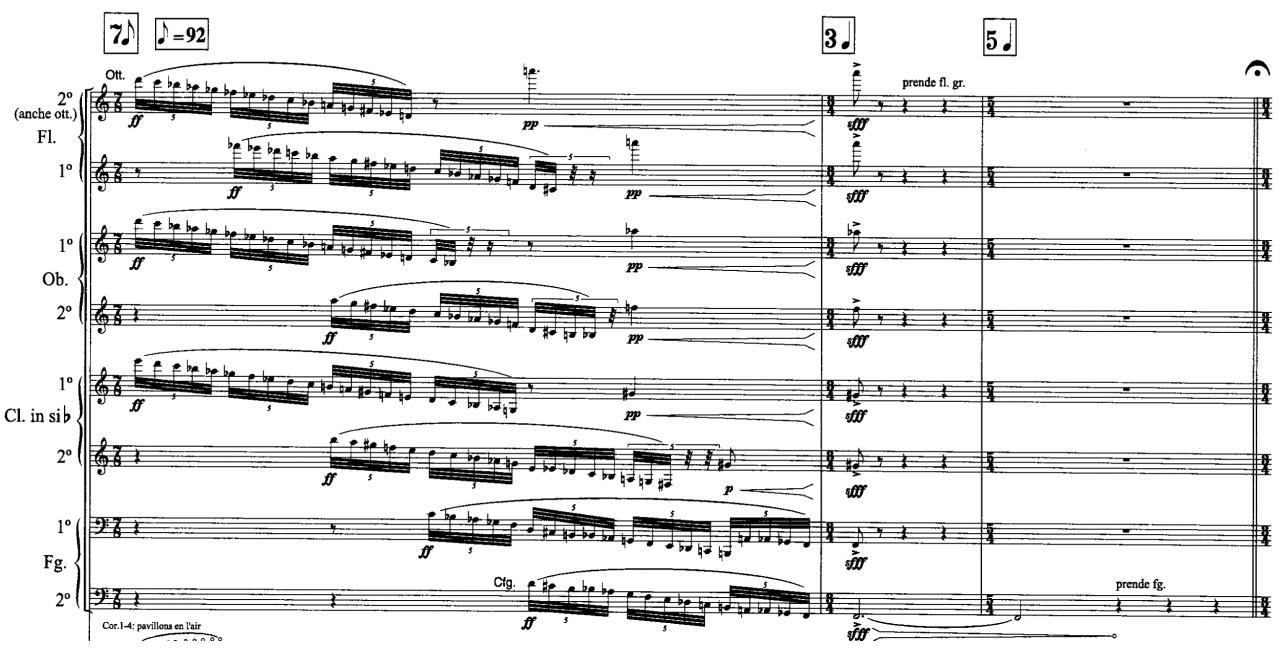

Por último, dejando el análisis de Si después de morir ... para otra ocasión, centremos la atención en Bruno o el Teatro de la Memoria, obra de la que realizó un texto preliminar Ignacio Gómez de Liaño ${ }^{6}$, facilitado, por cierto, por Sotelo a Valente en un formato mecanografiado. Pese a su extensión, lo transcribo de manera integral en el Apéndice textual (6.3) por ser de difícil acceso como por el contenido que ofrece respecto al diseño global de la ópera.

\footnotetext{
la actualidad con Massimo Cacciari a efectos del libreto en italiano, se ha inspirado, además, en el preclaro humanista en prácticas escénicas como La cena de las cenizas, con la Orquesta Sinfónica de Galicia bajo la dirección de José Ramón Encinar. De otro lado, Valente se refiere explícitamente a Bruno al hilo de un viaje por pagos italianos entre el 8 y el 26 de abril de 1996 (Valente, 2011: 354). Por lo demás, su sensibilidad orientada hacia el pensamiento del humanista se remonta al 11 de mayo de 1961, según refleja en su diario a propósito de una reflexión sobre la «tradición del utopismo materialista» (Valente, 2011: 63). ${ }^{4}$ Valente (2008: 536).

5 SGAE 5.199.674 y ISWC T-042.667.506-0. Su estreno tuvo lugar en Madrid el 18 de octubre de 2001, con la Orquesta Sinfónica de RTVE, bajo la dirección de Antoni Ros, y la voz de Arcángel.

${ }^{6}$ De interés es al respecto su estudio consagrado a Expulsión de la bestia triunfante (Bruno, 1987).
} 


\section{2. "NATURA EST DEUS IN REBUS»: UN PROCESO DE COMPOSICIÓN IN FIERI COMO ARTE DE LA MEMORIA}

Con el objeto de desentrañar el papel medular que desempeñó Valente en Bruno..., habremos de tomar en consideración las palabras de Sotelo en el texto prologal de $\mathrm{Si}$ después de morir ... In memoriam José Ángel Valente. Y es que el compositor, en este paratexto fechado en diciembre de $2003^{7}$, subraya los lazos poético-musicales entre Luigi Nono, al que Sotelo le ha dedicado Nel suono indicibile - a Luigi Nono o Cripta. Música para Luigi Nono ${ }^{8}$, y Valente que cristalizaron en su proyecto de ópera sobre la inmolación de Bruno en la hoguera. Desde esta atalaya estética, Sotelo parte de conceptos gratos al poeta como «escucha» $\mathrm{y}$ «memoria», es decir, arte de la memoria a la manera de Bruno y Nono ${ }^{9}$. Para ello, pone énfasis en la expresión melismática tanto del canto como del cante por su dimensión microvocálica, microinterválica y microtonal, con puntos de encuentro respecto al Arte povera ${ }^{10}$.

Figura 2. Si después de morir...: indicaciones para 3/4 de tono, microintervalos y trinos microinterválicos (Sotelo, 2003c: I)

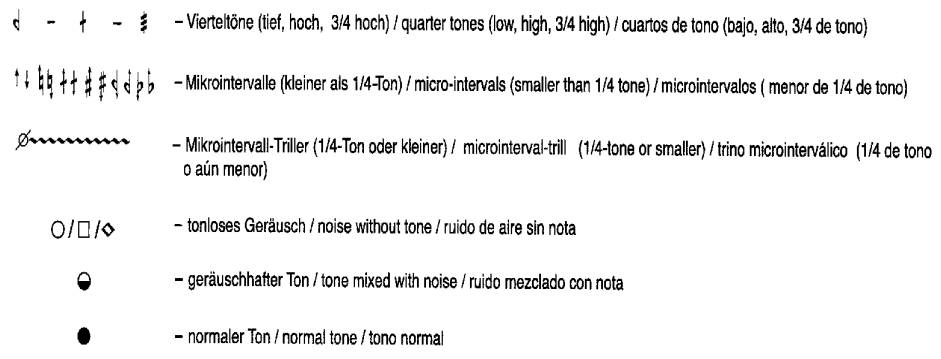

De otro lado, refiere más adelante el compositor que de esta empresa operística nacieron poemas esenciales de Valente como "Tamquam centrum circuli», con asesoramiento conceptual de Gómez de Liaño y ecos morentianos, según tendremos la ocasión de comprobar, $\mathrm{y}$ «Campo dei fiori, 1600», y en lo que hace a su labor compositiva, In pace y De magia, obras estrenadas en el Círculo de Bellas Artes de Madrid, estando presente el poeta ${ }^{11}$. Señala también en este contexto Sotelo que, de entre sus obras, la favorita de Valente era De amore, inspirada en el tratado homónimo del humanista neoplatónico Ficino.

\footnotetext{
${ }^{7}$ Sotelo (2003a: 9-11).

8 Sotelo (1997) y Raposo (2009).

${ }^{9}$ Este último a modo de puente modulatorio entre el dodecafonismo de Webern y la escuela de Grisey, Dufourt, Murail y Radulescu. Se trata, en efecto, de la descomposición microscópica o «radiografía» caleidoscópica del sonido en sus microcalidades esenciales, con calado fractal en el compositor madrileño al trasluz de ecos morentianos (Sotelo: 2001).

10 Aguirre (2014).

${ }^{11}$ De magia (1995) remite, de hecho, al título de un tratado redactado por Bruno en 1590. En sus páginas el humanista alude tanto a una tipología de demonios que poblaban el universo como a la teúrgica o teopéyica, práctica mistérica relacionada con la escritura del universo como jeroglífico, de influencia en Valente y Sotelo.
} 
Por tanto, la colaboración de Valente en dicha ópera dio como fruto, de entrada, dos poemas medulares ${ }^{12}$, además de otros fragmentos inéditos ${ }^{13}$, en diálogo intertextual con Sotelo, según se colige de una primera carta, inédita hasta la fecha, que le escribe el compositor al poeta en 1995 como fruto de este proceso de composición in fieri o work in progress. Se trataba, en síntesis, de una fase avanzada del proyecto iniciado en 1993, a raíz de una conversación telefónica, y que contaría con una primigenia versión del libreto el 26 de agosto de 1996 con el arranque «Oscuro es como la noche el canto». Sin embargo, este tempo ágil tendría una suspensión por razones de trabajo de Sotelo durante dos años, con motivo de una obra encargada por Peter Ruzicka para la Bienal de Teatro Musical de Munich, si bien se retomaría a finales de 1999, ya con deterioro de la salud de Valente, a quien tuvieron el propósito de visitar, aunque sin que se llevara a término, el compositor acompañado de Morente ${ }^{14}$. En cualquier caso, dice así la carta:

Collado Mediano, 31.5.1995

Querido José Ángel, no puedes imaginar la alegría que me produjo recibir tu primera «entrega» de nuestro Teatro de la Memoria.

El texto es maravilloso y creo que va a funcionar muy bien con la música. Ya estoy trabajando en la obertura pero, antes de seguir avanzando, quisiera consultarte algunos puntos que, sin más, paso a comentarte.

1/. La «Primera Voz» es hermosísima. Va construyendo desde el abismo un palpitante crescendo, que un ritmo interno, cada vez más perceptible, conduce a lo que yo ya denomino «Acorde solar», una de las columnas estructurales de la obra.

\footnotetext{
12 En una entrevista concedida a Fernández Quesada (2000: 145), Valente no se refiere a estos poemas de manera específica sino tan solo a un texto sin concretar que había preparado para esta ópera.

${ }^{13}$ Que edito en el presente artículo. Otros, en cambio, han sido recogidos en Valente (2006: 562-563). Es el caso de «Fábula», incluido en Fragmentos de un libro futuro, a partir del lamento de Asclepios en Spaccio de la bestia trionfante de Bruno (véase más abajo):

Sólo queda la fábula.

Lo que se narra y al narrarse crea

la sola narración para ninguno.

Tiempo.

No podemos morir.

Quedan tiempo y escucha para oír lo celeste.

Ahora

ven a mí, cubre mi cuerpo con tu espeso velo, sueño, despierto sueño de los dioses.

Y yo

me acordaré de ti y de otro canto.

14 Véase más adelante y también el Apéndice textual. En cuanto a la vida y obra del cantaor, interesado en músicos como Nono o Lachenmann: Gutiérrez Quesada (1996).
} 


\section{de Bruno}

Figura 3. Representación autógrafa del «Acorde solar» por Sotelo a la estela

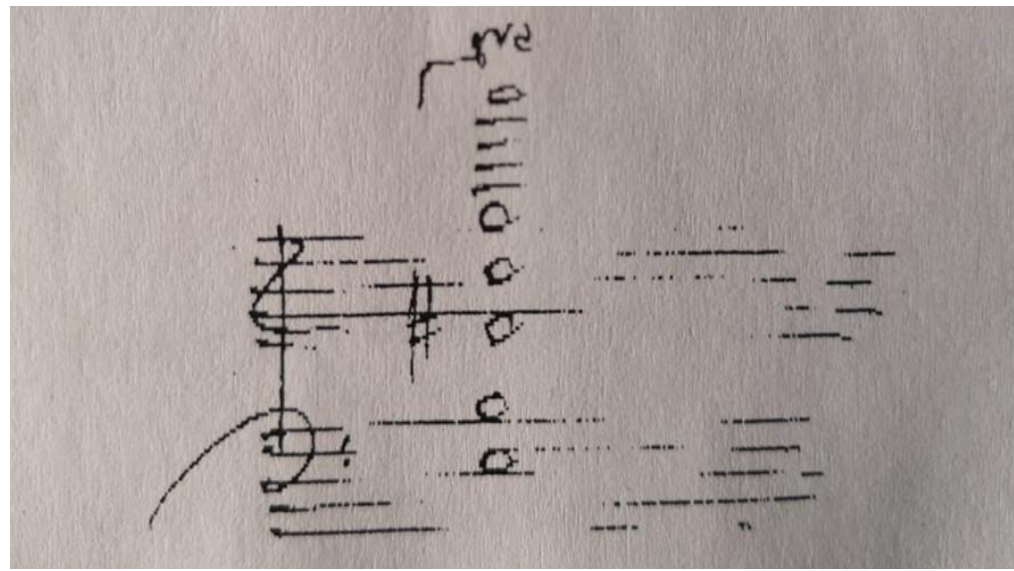

Temo, sin embargo, que esta «ascensión» y paulatina iluminación pueda resultar excesivamente larga, por lo que sugiero, si es posible, «condensar» algunos versos (Con una doble línea // te señalo aquellas partes que, desde mi punto de vista, serían susceptibles de ligera modificación. Ver Anexo 1).

Dime, por favor, qué piensas. Si crees que algún recorte perjudique [sic] el texto, podría yo intentar una solución musical.

2/ No sé si, en un primer momento, la elección del soneto de Bruno sobre el «Pájaro solitario» ha sido la más acertada para la primera intervención de su «Voz». Pienso que esta debería tener un cierto tono desafiante pero sereno...; no sé cómo expresarlo, pero definir el carácter de esta «Voz de Bruno» me resulta ahora tarea fundamental, no solo para este momento sino para toda la ópera.

Te envío copia del 3er Soneto que introduce el De l'infinito que creo contiene los elementos que necesitamos (ver Anexo 2).

La extensión ideal sería de 6 versos (Sello Solar).

3/ Por otra parte, he pensado en la necesidad de cerrar el círculo que se abre con la obertura, componiendo esta y el epílogo (Cuadro 30 «Erato») como un gran «canto» en 2 «tiempos». Se me ocurre, para el epílogo, combinar algunos de los elementos temáticos que aparecen en tus poemas «Oscuro es como la noche el canto»y «Venida de lejos». De cualquier modo, concebir principio y fin como una unidad: poema cantado al que las imágenes acompañan como sombra o Luz.

Te envío copia de un fragmento del ensayo de M. Á. Granada que acompaña su traducción de Spaccio [de la bestia trionfante]. Aquí hay algunas claves interesantes sobre la «reforma» en esta obra bruniana: «Natura est deus in rebus» [Anexo 3].

4/ La Universal en Viena me pide si pudiésemos enviarles una breve sinopsis argumental y comentario, que pudiesen utilizar ya para «Promotion». Tres óperas americanas estarían también interesadas en la ópera y necesitan pronto algún material sobre nuestro Teatro. Le pediré a Ignacio [Gómez de Liaño] que te llame para ver si disponéis de tiempo para hacer algo así. Yo, por mi parte, escribiré un breve texto sobre el material sonoro.

Recibe un fuerte abrazo,

Mauricio

Esta primera carta de Sotelo a Valente ofrece además un contenido complementario referido a la ópera, que se inicia con el «Anexo 1» circunscrito al Cuadro I. Varios versos, efectivamente, presentan marcas suyas (//) al hilo de reajustes del texto poético en clave musical, contexto en el que la omnipresencia de Mnemosine y su espacio 
arquitectónico o Teatro de la Memoria ${ }^{15}$, con huellas del De Imaginum signorum et idearum compositione bruniano, podría llegar a justificar que la ópera pudiera haberse titulado Mnemosine o el Teatro de la Memoria ${ }^{16}$. Es más, la escenografía debía estar preparada para el 2005 gracias a Jaume Plensa, a petición de Valente antes de su fallecimiento, y con puesta en escena de Carlos Padrissa y Àlex Ollé, de La Fura dels Baus. En cualquier caso, el arranque del Cuadro I es el siguiente:

\section{CUADRO I}

Las tinieblas y la luz (Orco; Apolo)

(El escenario estará en sombra, cruzada sólo por ráfagas de luz tenue, como naciente. La primera -y más importante- voz debe oírse, pero no ha de verse al barítono. Estará en la zona de sombra.)

Primera voz:

Oscuro es como la noche el canto.
En el Orco no existe la memoria.
Ya no o todavía.
No pueden los muertos recordarnos.
Porque han bebido el agua de la fuente Leteo
// y no podrían recordar lo viviente.

Resucitar es beber en las aguas

de Mnemosine,

la fuente de la luz que puede

bajar segura a los dioses del fondo

hasta incendiar la sombra.

El Orco.

// Musgo, humedad, arcillas, limo,

fenómenos del fondo,

de los barros oscuros

donde las figuras de los sueños se forman.

// Sordas insignias de la sombra.

Animal que palpita.

Lo que palpita tiene

un ritmo y por el ritmo adviene,

recibe y da la vida.

En lo oscuro

el centro es húmedo y de fuego.

Madre, matriz, materia,

stabat matrix.

Rompe desde un sombrío abismo el sol.

\footnotetext{
15 Como en el caso de Sotelo, se detectan implicaciones conceptuales procedentes de la arquitectura en otros compositores estésicos que implementan el palimpsesto interdisciplinar como José María SánchezVerdú, con influencia de artistas plásticos del calado geométrico-musical de Palazuelo; baste recordar sus Arquitecturas de la ausencia, con movimientos como Arquitectura de espejos y ecos o Arquitectura del silencio.

${ }^{16}$ Como se lee en una entrevista de Sotelo concedida a García Calero para $A B C$ el 18 de julio de 2001, por tanto, un año después del fallecimiento de Valente.
} 
Apolo,

el parto ardiente de la noche vino.

Si bien la versión redaccional prístina la edito en el Apéndice textual, en cambio, traigo a colación el «Anexo 2» que el compositor compartió con Valente. Me refiero a un soneto al frente de De l'infinito $(1584)^{17}$, con puntos de encuentro respecto al cap. I, 1 del también bruniano De immenso et innumerabilibus seu De universo et mundis (1584). Sobre este particular, procede Sotelo conforme a la indicación de que dicho soneto podía servir para la «Obertura» en la «Voz de Bruno»:

Hay quien me empluma y quien me inflama el pecho, quien me hace no temer fortuna o muerte, quien rompió las cadenas y aquellas puertas de donde pocos se ven sueltos y salen fuera.

Las edades, los años, los meses, días y horas, hijas y armas del tiempo, y toda esa corte ante quien ni hierro ni diamante es fuerte de su furor me han puesto a salvo.

Por eso las alas al aire seguras abro y no temo chocar con cristal o vidrio, mas surco los cielos y al infinito me alzo.

Y mientras de mi globo a otros surjo y por el etéreo campo más allá penetro, lo que otros ven lejano, yo, a mis espaldas dejo.

Asimismo, en dicha misiva, Sotelo facilitó a Valente un tercer documento para la génesis evolutiva de la ópera; en concreto, corresponde a los siguientes párrafos de Miguel Ángel Granada, extraídos de su estudio introductorio a la traducción de Spaccio de la bestia trionfante ${ }^{18}$, que ceñimos, en aras de la economía discursiva, a los marcados por Sotelo con el objeto de orientar y dirigir la lectura del poeta:

VII. La recuperación del perdido coloquio con los dioses: «Natura est deus in rebus»

En el De rerum natura decía Lucrecio: «hunc igitur terrorem animi tenebrasque necessest / non radii solis neque lucida tela diei / discutiant, sed naturae species ratioque» (I, 146-148); la liberación moral es fruto del conocimiento racional de la naturaleza. Similarmente en Bruno la recuperación de la correcta noción del universo, expuesta en los tres diálogos cosmológicos, comporta una reforma moral, política e incluso religiosa, porque con el acceso a la verdadera cosmología tiene lugar inevitablemente la adquisición de una verdadera noción de Dios y del hombre y sobre todo el restablecimiento de una correcta relación y comunicación entre ambos a través de la mediación de la naturaleza. [naturaleza con subrayado autógrafo]

[...] Natura est deus in rebus [Natura est deus in rebus con subrayado autógrafo] reza la fórmula del Spaccio [de la bestia trionfante] (p. 257) que sintetiza el pensamiento bruniano. A través de la naturaleza tiene lugar el acceso y comunicación del hombre con la divinidad: por un lado a través de la religio-lex (hecho natural y cuya función, como veremos, es inmanente al mundo); por otro a través de lo que Bruno denomina «voces vivas» (en oposición a una voz «muerta», que sería el lenguaje verbal), esto es, los efectos

\footnotetext{
17 Bruno (1993).

18 Bruno (1989: 58-64), con reed. rev. en 1995.
} 
naturales, las cosas naturales, en tanto que expresión, contracción y ofrecimiento de la divinidad $[\ldots]$.

Y es que, realizados los reajustes necesarios en clave musical, Sotelo volvió a remitir a Valente, ya enfermo, su versión del texto, circunscrita al Acto I de la ópera ${ }^{19}$, acompañada de esta nota: "Caro maestro, aquí la posible versión "ligera" del primer Acto para que la "visualices". Espero con ansiedad tu veredicto. Un abrazo y que te mejores. Mauricio»».

Ahora bien, una vez planteado el proceso de colaboración in fieri entre Sotelo y Valente, pasemos al análisis circunscrito a la primera de las composiciones más destacadas del poeta orensano, "Tamquam centrum circuli», que nacieron de esta obra operística, como se deduce del último fragmento de esta segunda notificación de Sotelo, en la que, según se puede ver en el Apéndice textual, se menciona de manera explícita el nombre de Morente, en calidad de intérprete del poema para coro y orquesta: «(9.) Tamquam centrum circuli / (Morente, Cori, Orch.)». Tanto es así que Morente será un referente esencial en la escritura musical de Sotelo, principalmente en la década de los noventa en la que trabajaron al alimón. Se concreta, de hecho, en obras del calado de $\mathrm{Su}$ un oceano di scampanelli per piano forte solo (1994-1995), con resonancias de Ungaretti e indicación «lento, intenso, "Morente"»:

Figura 4. Su un oceano di scampanelli per piano forte (Sotelo, 1995: 6)

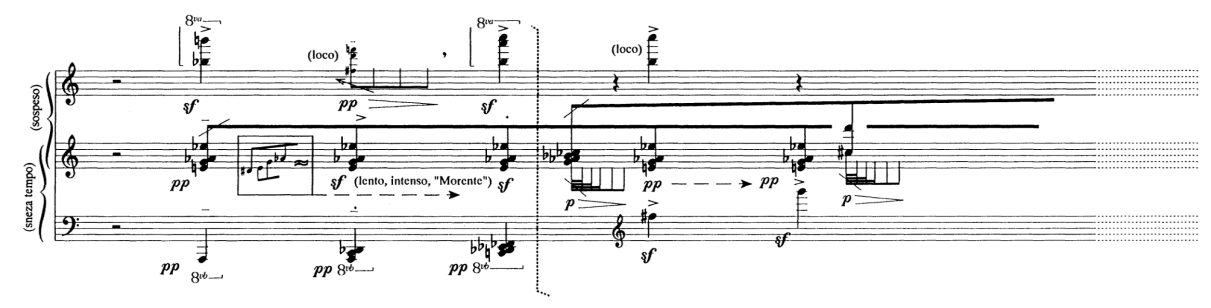

Figura 5. Su un oceano di scampanelli per piano forte (Sotelo, 1995: 14)

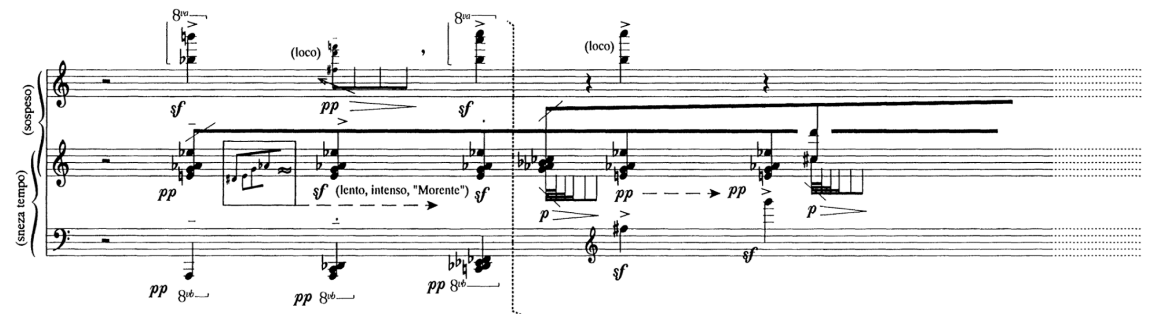

Figura 6. Su un oceano di scampanelli per piano forte (Sotelo, 1995: 17)

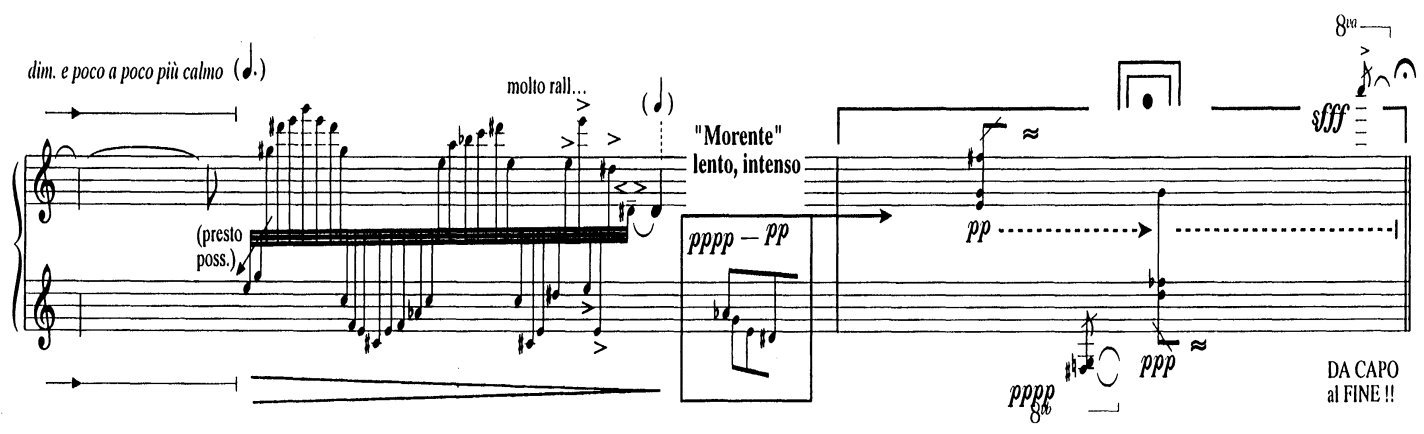

${ }^{19}$ Véase el Apéndice textual. 
Pasemos a profundizar en esta cuestión.

\title{
3. «TAMQUAM CENTRUM CIRCULI» (CON ECOS DE LA VITA NUOVA) O «VOZ DE DOLOR Y CANTO DE GEMIDO» AL TRASLUZ DE BRUNO-MORENTE
}

Uno de los poemas clave que compuso Valente para Bruno ... lo tituló, en efecto, "Tamquam centrum circuli», incluyéndolo, con posterioridad, en Fragmentos de un libro futuro. Lleva como fecha el 6 de enero de 1996, década en la que Sotelo estaba trabajando con Morente; de ahí la mención de su nombre en el estadio redaccional que compartieron el compositor y el poeta. Por lo demás, su versión definitiva no presenta variantes significativas:

\author{
LA MEMORIA nos abre luminosos \\ corredores de la sombra. \\ Bajamos lentos por su lenta luz \\ hasta la entraña de la noche. \\ El rayo de tiniebla. \\ Descendí hasta su centro, \\ puse mi planta en un lugar en donde \\ penetrar no se puede \\ si se quiere el retorno. \\ Se oye tan sólo una infinita escucha. \\ Bajé desde mí mismo \\ hasta tu centro, dios, hasta tu rostro \\ que nadie puede ver y sólo \\ en esta cegadora, en esta oscura \\ explosión de la luz se manifiesta ${ }^{20}$.
}

En estos versos, Valente ofrece una armonización de motivos que relaciona con la música: el arte de la memoria, por influencia de Bruno, el claroscuro poético como fusión y equilibrio de contrarios, el tempo lento del descenso y la escucha detenida y sin fin a modo de perpetuum mobile, así como la revelación-epifanía concretada en «Bajamos lentos por su lenta luz», «El rayo de tiniebla» y «[...] en esta oscura / explosión de la luz se manifiesta». En este contexto de revelación mistérica en el que la divinidad pura o Ungrund en Boehme mora en el interior del hombre, como deus absconditus ${ }^{21}$, se inscriben, además, imágenes como la noche-tiniebla en consonancia con la memoria, agente que facilita dicho descenso, mientras que la del «rayo oscuro», equiparado al Lógos-Espíritu, está vinculada al fulgor en «los bordes extremos de la luz», como una oscuridad luminosa plasmada mediante el oxímoron característico de la mística ${ }^{22}$.

En esta poética del límite y del dios del lugar se ubica no solo el rayo de tiniebla, cantado por Morente, en calidad de símbolo de lo numinoso y la trascendencia divina, sino también la imagen de la «entraña» de la noche. Ello remite, de un lado, al concepto místico presente en el Cántico espiritual, como recoge Valente en su poema «La nada»,

\footnotetext{
${ }^{20}$ Valente (2006: 562).

${ }^{21}$ Lo manifiesta el poeta en su interpretación del arranque del Cántico espiritual (Valente, 1997: 37).

${ }^{22}$ Valente (2008: 460; 2011: 228).
} 
y, de otro, a la noción mística de lo entrañal en Un descenso a los infiernos (1995) de María Zambrano, que la filósofa suele asociar al descenso ad Inferos o catábasis ${ }^{23}$, según habían compartido el poeta y Sotelo.

Sea como fuere, esta deuda respecto a la filósofa malagueña explica, a su vez, la importancia del símbolo del centro asociado a la divinidad, en un nuevo recuerdo a Zambrano, que Valente hermana con el de la piedra, como se comprueba en sus ensayos; es el caso de «La piedra y el centro», «El sentido de la copla flamenca» y otros relacionados con el flamenco, la tradición oral y su estancia vital en Almería ${ }^{24}$, en la que forja su última obra, Fragmentos de un libro futuro, a la que pertenece este poema, aunque con origen en la ópera que estoy analizando.

Destacan, igualmente, como referentes del poema la «escucha infinita» como símbolo de perfección y, sobre todo, el retorno, que está asociado a la vuelta, el regreso al origen (arché) o punto cero en el que comienza el arte trascendente. Sobre este particular, en sus ensayos y otros textos críticos, Valente venía dedicando visible espacio al retorno, que relaciona con principios musicales y directrices identificables en otras artes. De hecho, en el texto titulado «Retorno», el poeta muestra su interés no solo por la música antigua y contemporánea, lo que justifica esta labor de cooperación interdisciplinar con Sotelo, sino también por el discurso musical asociado a los distintos pueblos; así, le interesó la música de su tierra, el tango argentino o los sones afrocubanos ${ }^{25}$.

Por otra parte, el origen en "Tamquam centrum circuli» remite a la búsqueda e indagación del centro mediante el tempo lento, es decir, conforme a la escucha y lectura detenida planteada por Bruno, como le transmite Sotelo a Valente en la correspondencia referida. Como resultado, se llega, en fin, a la epifanía y a la luz como revelación, de ahí que Valente, en Fragmentos de un libro futuro, dedique a esta cuestión el poema titulado «Centro», en el que se alude al tempo lento en dos imágenes: «por lentos corredores»y «de lenta sombra $[\ldots]{ }^{26}$.

Pues bien, relacionado con el origen se distingue otro de los conceptos filosóficos que adquiere especial calado en «Tamquam centrum circuli»: la «nada». En este sentido, como sucede con su lectura estética de la poesía y la música en este poema, Valente reconoce en la pintura de Tàpies el principio místico de la «nada» como inicio del proceso compositivo, según pone de relieve en "Cinco fragmentos para Antoni Tàpies» ${ }^{27}$. Por ello, goza de relevancia en "Tamquam centrum circuli» el hecho de que el artista parta del «espacio vacío» o «en blanco», no adulterado por tanto por cromatismos artificiales del hombre, y el «punto cero» a fin de «vaciarse a sí mismo» y poder adentrarse en su interior. Actúa de esta suerte, en suma, con el objeto de crear un nuevo lenguaje en virtud de un ejercicio de poetogénesis.

Finalmente, relevancia le concede Valente a la bajada o catábasis a la interioridad, al igual que sucede en la poética de lo jondo, descenso que, en realidad, se trata de una subida espiritual hacia el conocimiento, a la manera del poema «Elogio», dedicado a Chillida, de Andrés Sánchez Robayna, con puntos de encuentro respecto al imaginario de Valente y Sotelo ${ }^{28}$.

\footnotetext{
${ }^{23}$ Martínez González (2008).

${ }^{24}$ Con La Chanca, El Taranto y Tomatito en el recitado de poemas: Escobar (2012a, 2013).

${ }^{25}$ Valente (2008: 1535) y Escobar (2019).

${ }^{26}$ Valente (2006: 580).

${ }^{27}$ Aguirre (2016).

${ }^{28}$ Sotelo (2003b).
} 
En efecto, en virtud de una cadena de relaciones intertextuales, nuestro autor vincula el descenso ad Inferos de Bruno a La vita nuova de Dante ( Ego tamquam centrum circuli, cui simili modo se habent circumfenrentie partes; tu autem non sic», XII, 4), por lo que el poeta toma para el título de su composición la iunctura «[Ego tamquam] centrum circuli» («[Yo soy] como el centro de un círculo»). Estamos, en cualquier caso, ante un contexto filosófico-musical en el que Sotelo equipara, en virtud de una correspondencia simbólica y salvando las distancias, claro está, la figura de Morente al personaje literario de Bruno debido a la aportación transgresora de ambos artífices en sus respectivas épocas y campos disciplinares ${ }^{29}$.

Sea como fuere, por una anotación concreta del diario de Valente sabemos que el poeta estaba trabajando ya, de modo embrionario, el 30 de agosto de 1980 en este leitmotiv recreado por Dante como estadio prístino de su poema. Además, llega a establecer un paralelismo analógico entre centrum mundi y a punctum mundi a partir de otro pasaje perteneciente al «Paradiso» (XXVIII) con motivo de la luz simbólica que viene a evocar la epifanía, revelación o «fulgor». Concluye, en fin, su nota Valente con la relación que propone entre esta simbología y el pensamiento filosófico de Zambrano por la tradición órfica y el descenso ad Inferos ${ }^{30}$, esencial en el pensamiento y poética musical de Sotelo.

Es más, en consonancia con esta influencia de la Vita Nuova en "Tamquam centrum circuli» y con el propósito de enfatizar la armonía que preside dicho descenso como principio fundamental en la tradición órfica, Valente se vale de la analogía pitagórica cada cinco versos en calidad de símbolo de la perfección conforme al círculo de quintas en la teoría musical de occidente ${ }^{31}$. Al mismo tiempo, conforme a este modus operandi, Valente conectaba, a su vez, tanto con la concepción numérica contemplada por compositores como Webern o Schönberg, modelos para Sotelo desde la estética dodecafónica y la poética del silencio $^{32}$, como con las implicaciones simbólicas propuestas por Zambrano en sincretismo, además para Valente, con la espiritualidad zentaoísta; de ahí que el poeta relacionase, en la anotación del diario, su pensamiento de aliento órfico-pitagórico con el de la filósofa malagueña, quien había escuchado flamenco desde su niñez, especialmente los ecos de Juan Breva.

Asimismo, estas correspondencias numéricas vienen a entroncar con las nociones mágico-cabalísticas defendidas por Bruno, con calado en Sotelo y Valente, como hemos visto a la luz de las misivas mencionadas. Quedan destacados, en este sentido, los versos esenciales del poema de Valente en los que se recogen sus claves principales, a saber: «El rayo de tiniebla», que influyó en José Moreno y su acuarela Rayo de tiniebla, «Se oye tan sólo una infinita escucha» ${ }^{33}$ y «explosión de la luz se manifiesta», como revelación o epifanía. Este último motivo lo toma precisamente Valente de su traducción del prólogo al Evangelio según San Juan («Kata Ioanem»), en concreto, de los versos «Y la luz brillaba en las tinieblas / y las tinieblas no la han hecho suya.» ${ }^{34}$.

\footnotetext{
${ }^{29}$ Lo que justifica, en efecto, que le pusiera voz el cantaor granadino.

${ }^{30}$ Valente (2011: 200).

${ }^{31}$ Díaz Gamboa (2009).

${ }^{32}$ El primero con puntos de encuentro para con el espectralismo (Lai, 2008; Ramos, 2012; Dufourt, 2014; Campos, 2017; Besada y Ordóñez Eslava, 2019). De hecho, en consonancia con la línea silente y electroacústica de Cage y Stockhausen y el IRCAM a la luz de Saariaho, Lindberg o Benjamin, esta corriente constituye la base para el flamenco espectral de Sotelo (Gan, 2008) a partir de herramientas en el proceso de grabación y de análisis de la onda sonora como ProTools o Melodyne.

${ }^{33}$ Según Sotelo (2003a: 10), este verso resume su lema estético compartido con Valente.

${ }^{34}$ Valente (2006: 619).
} 
Es más, continuando con esta serie de equivalencias simbólico-filosóficas en torno al cinco en «Tamquam centrum circuli», Valente tiene en cuenta, a nivel de poética, los cinco capítulos del Génesis, de suerte que el «origen» o punto en que se regeneran de manera perpetua las «formas» lo asocia, de un lado, al arranque prologal del referido Evangelio de San Juan y, de otro, a Tres lecciones de tinieblas, con la explicación metapoética en lo que hace a la letra hebrea $\mathrm{Bet}^{35}$. Como resultado, tiene lugar la «palabra matriz», «palabra inicial o antepalabra» como lógos espermático o palabra seminal, lo que recuerda el vocablo «matrix», en diálogo con «matriz» y «mater» de Tres lecciones de tinieblas por la raíz indoeuropea matr- asociada al principio de lo femenino ${ }^{36}$ y muy presente en Bruno ..., junto a otros ecos en composiciones de Sotelo como Intermezzo II (Matriz-Materia) en De oscura llama. A su vez, el oxímoron del poeta referido a la imagen lumínica y de la tiniebla en «Tamquam centrum circuli» se conjuga, pues, con el descenso-ascenso, que se realiza mediante el tempo lento («Bajamos lentos por su lenta luz / hasta la entraña de la noche.») y que lleva al centro («Descendí hasta su centro» y «Bajé desde mí mismo / hasta tu centro, dios, hasta tu rostro»).

Ahora bien, el trabajo interdisciplinar de ambos artistas a propósito de «Tamquam centrum circuli» acusó un proceso de retroalimentación o feed-back, ya que, aunque, al decir de Sotelo, en este poema influyó Bruno..., esta labor compartida permitió al compositor ofrecer obras, con diferentes variaciones a nivel de textura tímbrica. De hecho, partían de la lectura estético-filosófica de nuestro autor en correspondencia intertextual con Bruno y hasta con Fernando de Herrera al hilo de sus versos «Voz de dolor y canto de gemido, / espíritu de miedo envuelto en ira». Así lo deja ver la ficha técnica de una obra suya en su página web, inspirada en la imagen «El rayo de tiniebla», que Valente insertó en «Tamquam centrum circuli».

Resulta visible, en consecuencia, cómo «El rayo de tiniebla» de «Tamquam centrum circuli» sugirió a Sotelo el título homónimo de esta composición para voz y orquesta, en la que, siguiendo las huellas morentianas, ha venido cantando Arcángel. Sus claves compositivas axiales fueron trazadas, en efecto, por Álvaro Guibert en el texto de presentación del concierto, celebrado en la Sala Sinfónica del Auditorio Nacional el 4 de junio de 2008, partiendo de la poética de Valente. Por lo demás, viene a recordar cómo la imagen elegida se remonta al Pseudo-Dionisio (V y VI d. C.), en su Mystica theologica, en virtud de "caliginis radium» ('rayo de tiniebla'), y pasa, mediante un proceso de reescritura, por la recreación de San Juan de la Cruz en la Subida al monte Carmelo para concebir el rayo como «la sabiduría del Dios secreta», en la medida que el alma del ser humano se encuentra entre «tinieblas» en aras de poder vislumbrar el «rayo» (iluminación divina) secreto y oscuro en su proceso de conocimiento hermético.

Guibert cita, de otro lado, el arranque del texto de Valente con cierre en «Descendí hasta su centro» ${ }^{37}$, al tiempo que pone de relieve reminiscencias de géneros del flamenco que vienen presidiendo la obra de Sotelo en la actualidad. Lo comprobamos a tenor de la seguiriya, según sucede en la modalidad de Curro Dulce grata a Sotelo en Si después de morir ..., con pervivencia al hilo de estructuras armónico-métricas en Wall of light black, Night y sobre todo a propósito de Rompe desde un abismo el sol (Seguiriya I) y Del amor oscuro (Seguiriya II) en De oscura llama. No faltan tampoco la granaína como Intermezzo I (Granaína) en De oscura llama y la soleá por bulerías, al modo de De la espiral secreta (Soleá por bulerías) en De oscura llama. Junto a estas formas, se identifican el martinete

\footnotetext{
35 Con loci communes respecto al discurso de Valente con motivo de la concesión del VII Premio Reina Sofía de Poesía Iberoamericana, que he consultado en su estadio mecanografiado primigenio.

36 Escobar (2012b).

37 Sánchez Robayna, por su parte (Valente, 2006: 562), ofrece una versión extensa de la composición, coincidente con el estadio redaccional que edito en el Apéndice textual.
} 
y la toná, como tienen lugar en Martinete de medianoche - Impromptu II (à la Neoperc) y Toná de mediodía en De oscura llama, así como la soleá, en la línea de Soleá de la sombra en De oscura llama y soleá espectral Alpha Centuri bajo los espacios sonoros de Do (C) y La b (A b) para el Ensemble Espai Sonor a la luz de la constelación de Centauro. Finalmente cabe destacar la bulería, como Bulería encendida en De oscura llama y con presencia en Sonetos del amor oscuro... o Wall of light black, con «cadenza segue sempre a tempo di bulería». De hecho, puede llegar a formularse «alla mente», en calidad de arte de tradición oral y debido a la influencia morentiana; por ejemplo en $\mathrm{Su}$ un oceano di scampanelli o De magia, en este caso con el intertexto machadiano «Caminante no hay camino» de Proverbios y cantares en El paseante (l'homme qui marche) por mediación conceptual de Nono. Veamos varios pasajes significativos:

Figura 7. Si después de morir...: seguiriya de Curro Dulce (Sotelo, 2003c: 41)

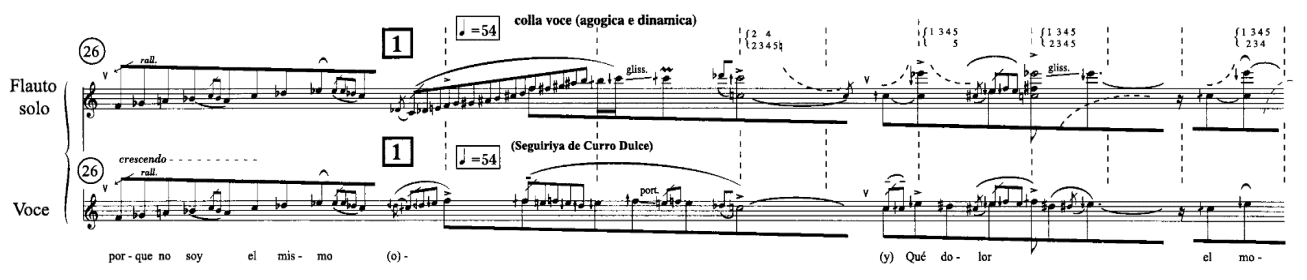

Figura 8. Si después de morir...: soleá (Sotelo, 2003c: 43)

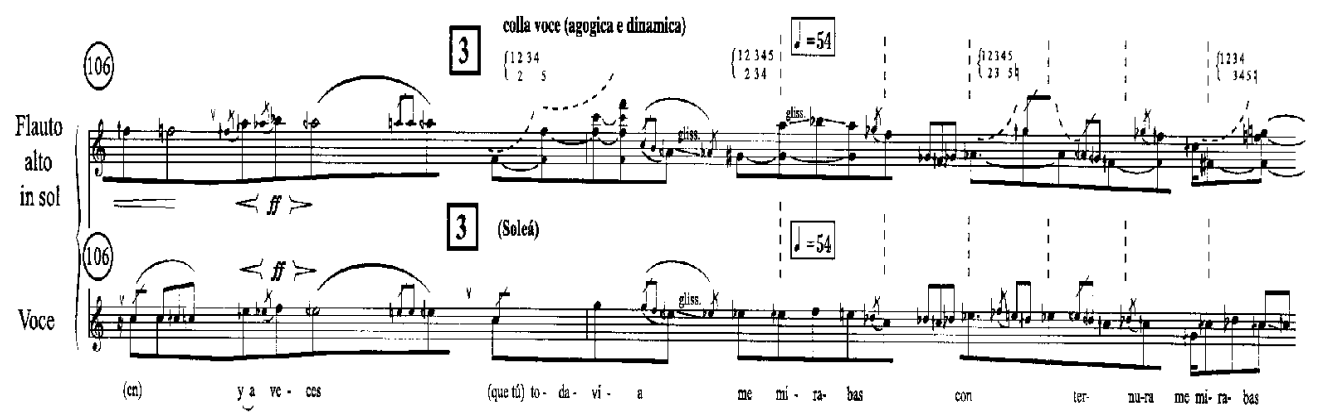

Figura 9. Sotelo, $S u$ un oceano di scampanelli per piano forte: bulería alla mente (Sotelo, 1995: 5)

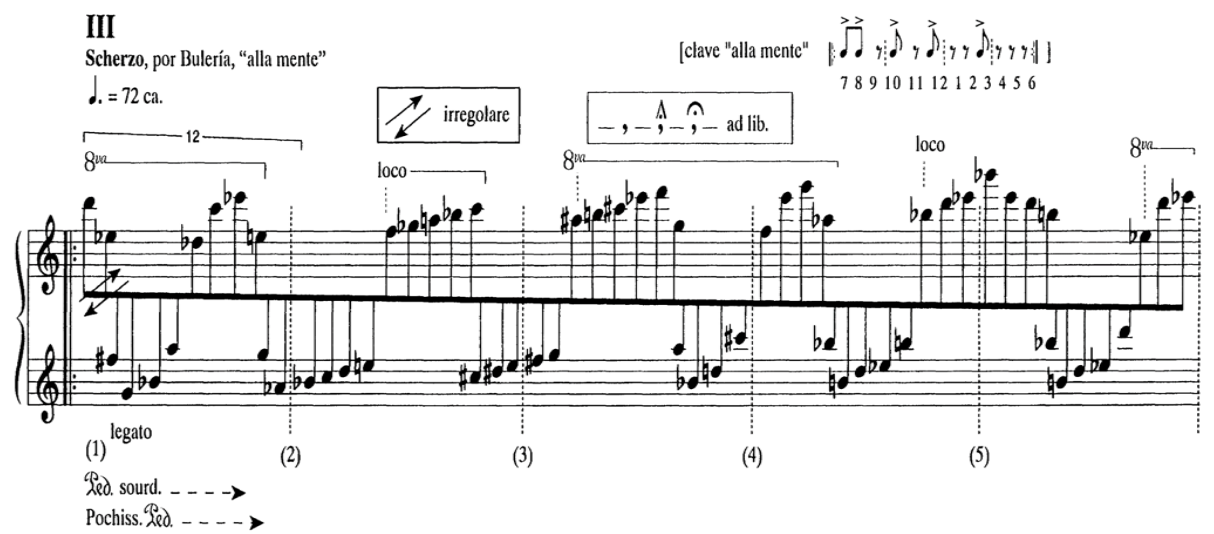


Figura 10. De magia per saxofono, percussione e piano forte: bulería alla mente (Sotelo, 2002: 7).

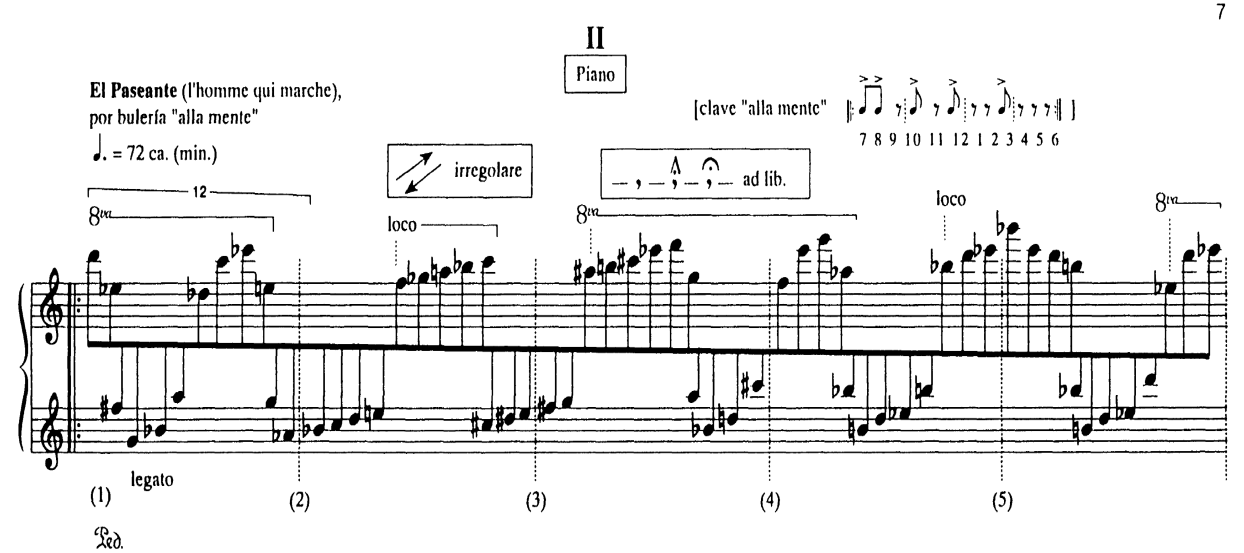

Y es que, en partituras como la de Chalan, Wall of light Red o Wall of light black, se acaba leyendo "come cante hondo» o "cantando, come cante hondo», incluso en esta última composición con «Hammer / martello» y «yunque», por su filiación con la toná y los estilos denominados de fragua, hoy en revisión crítica. Asimismo, en las figuras siguientes podemos hallar, en fin, otros ejemplos representativos a partir de scordatura, bien en virtud de la correlación armónica $6^{\mathrm{a}}=\operatorname{Do}(\mathrm{C})-5^{\mathrm{a}}=\operatorname{Sol}(\mathrm{G})-4^{\mathrm{a}}=\operatorname{Re}(\mathrm{D}) 3^{\mathrm{a}}=$ Sol \# $(\mathrm{G} \#)-2^{\mathrm{a}}=\mathrm{Si}(\mathrm{B}), 1^{\mathrm{a}}=\operatorname{Re} \#(\mathrm{D} \#)$, como refleja la maestra versión de Cañizares ${ }^{38}$, con resonancias lorquianas procedentes de La guitarra (1921):

Figura 11. Como llora el agua ... para guitarra: ritmo sordo por bulería, con scordatura (Sotelo, 2008: 11)

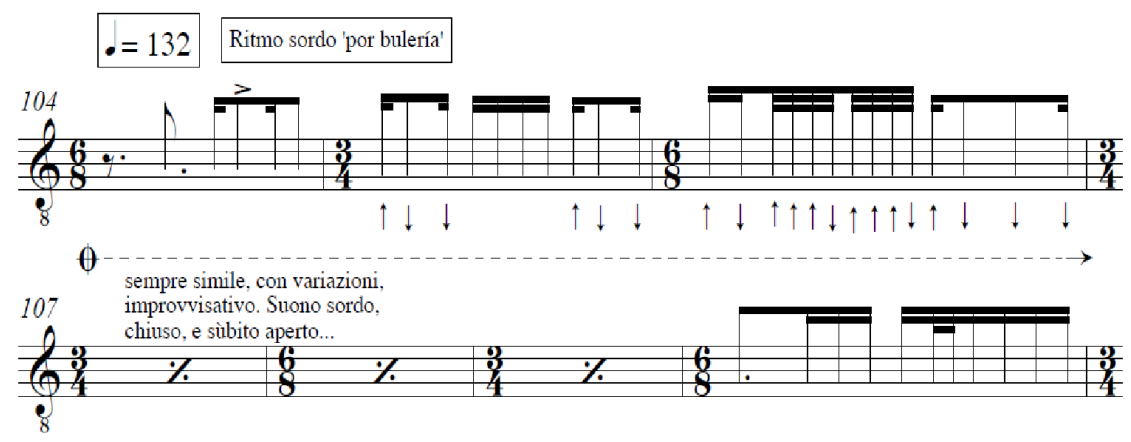

Figura 12. Como llora el viento ... per chitarra ed orchestra: scordatura (Sotelo, 2007: 4).

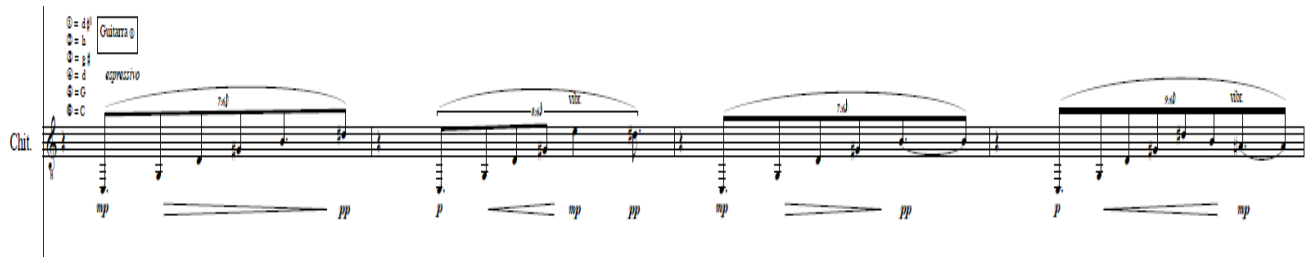

\footnotetext{
${ }^{38}$ Intérprete virtuoso que, junto a Arcángel, ha colaborado con Sotelo en un concierto-homenaje brindado a Valente en la Residencia de Estudiantes y más recientemente en la ópera, de sabor lorquiano, El público, con Heras-Casado, Rubén Olmo, el propio Arcángel, Jesús Méndez y Diassera (Carreira, 2016; Ordoñez Eslava, 2019b).
} 
O bien desde esta otra scordatura, $6^{\mathrm{a}}=\mathrm{Si}(\mathrm{B})-5^{\mathrm{a}}=\mathrm{La}(\mathrm{A})-4^{\mathrm{a}}=\operatorname{Re}(\mathrm{D}) 3^{\mathrm{a}}=\mathrm{Sol}$ (G) $-2^{\mathrm{a}}=\mathrm{Si}(\mathrm{B}), 1^{\mathrm{a}}=\operatorname{Re}$ \#-Mi b (D \#-E b), más habitual en el toque por seguiriya de concierto, como refleja Cañizares no solo en Como llora el viento ..., sino con anterioridad en su acompañamiento a la seguiriya de Morente en Flamenco (1995) de Saura:

Figura 13. Sotelo, Como llora el viento ... per chitarra ed orchestra: scordatura para seguiriya (Sotelo, 2007: 64)

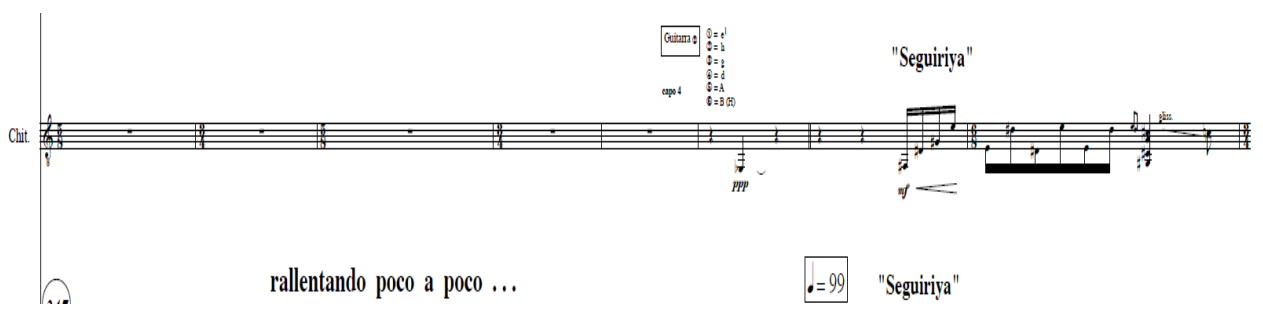

De otra parte, refería Guibert que, junto a la influencia del poema de Valente, se encuentran en Sotelo visibles huellas de fragmentos del flamenco, con las que el compositor estaba familiarizado desde su escucha atenta en la interpretación de Morente. Esta composición musical la había estado fraguando, por lo demás, años atrás, Sotelo con variaciones tímbricas en cuanto a texturas y en otros formatos, con el título Tamquam centrum circuli.

Pero pasemos, en fin, a analizar, en el apartado siguiente, la segunda composición poética valentiana de mayor calado morentiano que tuvo como génesis el diálogo interdisciplinar de Sotelo y el poeta orensano a propósito de Bruno o el Teatro de la Memoria.

\section{4. «EN LA INFINITUD DEL UNIVERSO Y SUS INNUMERABLES MUNDOS»: «CAMPO DEI FIORI, 1600» O BRUNO-MORENTE EN LA «HOGUERA»}

Como he venido apuntando, el segundo poema de Valente fruto de su labor cómplice con Sotelo, «Campo dei Fiori, 1600», tuvo también como protagonista a Bruno en tanto que no estuvo tampoco exenta de implicaciones morentianas. Pues bien, fechado el 17 de noviembre de $2000^{39}$ e incluido por el escritor, como «Tamquam centrum circuli», en Fragmentos de un libro futuro, el poema está dedicado al sacrificio público de Bruno en la hoguera preparada en la plaza romana Campo dei Fiori:

Y TÚ ardías incendiado,
sólo en la infinitud del universo
y sus innumerables mundos,
víctima de jueces
tributarios de sombra

hasta nosotros.

Pero tú aún ardes luminoso. y sombra

y sombra

Sombra

(Valente, 2006: 581)

${ }^{39}$ Si bien Sotelo lo recibió el 24 de febrero de ese mismo año. 
En estos versos, al igual que en "Tamquam centrum circuli», Valente realza la conjugación de contrarios ligados a la sombra y la llama luminosa, visibles en la poética musical de Sotelo, pero, en esta ocasión, con el objeto de denunciar, en mayor medida, la injusticia inquisitorial padecida por Bruno. De hecho, venía a servir al compositor para proponer, una vez más, la identificación simbólica entre Bruno y Morente a efectos de transgresión y renovación estética frente a ortodoxias y fanatismos no justificados. Se trata este, en cualquier caso, de un motivo temático que entronca con los primeros poemarios de Valente en los que deja ver ya su sensibilidad orientada a la crítica social contra los jueces injustos y el poder dictatorial, que atentan contra la libertad de expresión y la cultura ${ }^{40}$. Sin embargo, a modo de ascenso místico-iniciático, Bruno llega a trascender de manera alegórica en la llama purificadora, como le sucede a Morente en la encarnación performativa del humanista a la luz de Spaccio de la bestia trionfante hasta el punto de alcanzar «[...] la infinitud del universo / y sus innumerables mundos», como recuerda, en paralelo, Zambrano en su ensayo «La memoria del fuego», comprendido en De la aurora.

Incluso en el poema, al tiempo que se produce el ascenso de Bruno-Morente, los jueces se desvanecen en la sombra, o sea, en el descenso al infierno. Así lo pone de relieve la progresión, tanto a nivel semántico como visual, en el «espacio sonoro» del poema gracias a los espacios en blanco o silencios musicales en torno a la «sombra» que marca el descensus. Esta progresión la materializa, además, el poeta mediante recursos retóricoestilísticos, según refleja un trícolon con la conjunción copulativa que culmina, en fin, en un cuarto elemento como ostinato («sombra / y sombra y sombra [...]. Sombra.»).

Sea como fuere, al margen de la influencia de la música operística de Sotelo, esta disposición estructural entronca, a la par, con las simetrías compositivas de Busoni, Webern y Schönberg, en la música, o Kandinsky y Tàpies, en la pintura, en lo que hace al concepto de la diagonalidad y otras propiedades geométricas. Precisamente, en virtud de esta diagonalidad del poema-partitura, grata a Sotelo, Valente consigue un efecto de movimiento y dinamismo en el descenso, en tanto que establece una estructura circular en forma de ritornello, como eterno retorno y símbolo de la perfección; la construye, de hecho, entre el íncipit («Y tú ardías incendiado») y el éxplicit («Pero tú aún ardes luminoso.») $)^{41}$. La parte central del poema está presidida, en contraste, por la sombra, por lo que, en virtud del canon musical de cangrejo, Bruno-Morente, al igual que el ave fénix, Narciso o Lázaro valentianos, está destinado a la resurrección «en la infinitud del universo y sus innumerables mundos».

\section{5. «LA MÚSICA SE LEE EN EL AGUA»: CODA FINAL, CON UNAS ÚLTIMAS NOTAS MORENTIANAS}

A la vista del diseño conceptual de Bruno ... en el que Valente, en diálogo interdisciplinar con Sotelo, marida las artes, convirtiendo así sus poemas en auténticas composiciones sonoro-visuales, podemos decir, en suma, que su aportación, aunque inconclusa, enlaza con la tradición artística, de un lado, del llamado poema visual, con casos como los de Brossa, y, de otro, del grafismo o écfrasis musical, con Tàpies, Chillida, Oteiza o Palazuelo. Ello explica la sutil conjunción de sensaciones que Valente transmite al lector mediante un efecto de sinestesia multidireccional, con paralelos respecto al pensamiento musical de Zambrano, según se lee en «Entre el ver y el escuchar» (1970).

\footnotetext{
${ }^{40}$ Escobar (2012d, 2019).

${ }^{41}$ Con explicación por parte del poeta (Valente, 2008: 712) en un virgiliano guiño a La rama dorada (1890) de Frazer.
} 
Se trata este de un procedimiento expresivo, reconocible en Sotelo, que tiene sus paralelos en el influjo mutuo experimentado por creadores tales como Schönberg, en calidad de músico aunque con extraordinarias dotes para la pintura, o Kandinsky, maestro de la pintura pero interesado, a la par, en la aportación de la música en las artes plásticas. Seguramente, Valente abogó por este recurso técnico en la redacción de sus poemas habida cuenta del sabor contemporáneo que él y Sotelo querían otorgarle a la ópera conforme al pensamiento humanístico de Bruno. A su vez, el planteamiento de armonizar sensaciones estéticas procedentes de diferentes disciplinas, tan del gusto de Morente, estaba en consonancia con el concepto de ópera como arte total o programático (Gesammtkunstwerk), desde las aportaciones de Wagner hasta la escuela de Viena.

Ahora bien, para que el lector pueda paladear, por fin, de primera mano cómo se fue gestando este proyecto de colaboración entre Sotelo y Valente al trasluz de Bruno ofrezco, como cierre del presente artículo y a modo de Apéndice textual, fragmentos inéditos. Tanto es así que estamos ante variantes redaccionales in fieri que dieron carta de naturaleza a lo que pudo haber culminado en una ópera cerrada aunque, con el fallecimiento de Valente, no pudo llegar a buen puerto.

En cualquier caso, este interés interdisciplinar y de intersección de códigos llevó al compositor a tomar como referentes fragmentos de Valente para llevarlos a su universo compositivo, a la luz de su adaptación musical de las lecciones de tinieblas, con voz de Morente $^{42}$, correlato simbólico-vocal de Bruno, siguiendo las huellas de Tomás Luis de Victoria, pero también al calor de Tres lecciones de tinieblas, con impronta en el martinete de Morente sueña la Alhambra ${ }^{43}$, o Como el oscuro pez del fondo, íncipit de un poema de Cántigas de Alén; sin olvidar tampoco, claro está, Memoriae. Escritura interna sobre un espacio poético de José Ángel Valente y hasta su homenaje, con sabor valentiano, a Morente en Muerte sin fin para la Biënnale de Ámsterdam a partir del poema homónimo de Gorostiza, con Ed Spanjaard y el Nieuw Ensemble, la voz de Arcángel y la performatividad coreográfica de La Moneta.

Por último, en lo que atañe a la colaboración de Morente con Sotelo, en los años de conversación con Valente a propósito de Bruno, hay que destacar especialmente Expulsión de la Bestia Triunfante $(1995)^{44}$, con huellas de Spaccio de la bestia trionfante, que tuvo su estreno en el Festival de las Artes Sibila de Sevilla el 12 de marzo de 1996 en el Teatro Central de Sevilla con Arditti Quartet y el contrabajo de Scodanibbio. Esta fusión simbólico-ontológica entre Bruno y Morente, con jueces y cánones al margen, viene a explicar, en definitiva, que en el borrador del libreto de Bruno ... se mencione al cantaor como intérprete. Pero también este modus operandi da sentido a las microestructuras o microcalidades del sonido vocal morentiano conforme al flamenco espectral en El diálogo del amargo de Sotelo en Federico García Lorca. De Granada a la Luna (1998) ${ }^{45}$; por tanto también en la década de los noventa, en la que habían entablado un trabajo interdisciplinar Valente y Sotelo, y este con el cantaor granadino, cabal lector e intérprete sensible de los versos del poeta orensano.

En suma, en aras de la acribia investigadora y siguiendo el ideal virgiliano «Felix, qui potuit rerum cognoscere causas», hemos asistido a la escucha acusmática y receptiva, en términos compartidos por Valente y Sotelo, de visibles ecos transgresores de Morente. Para ello he partido de su diálogo sincrético-experimental con el músico madrileño hasta

\footnotetext{
42 Acompañado de la Orquesta del Klangforum de Viena y el Concentus Vocalis vienés, bajo la dirección de Sotelo en marzo de 1993.

43 Según se colige del arranque de las Tenebrae responsoriae a modo de polivocalidad.

44 SGAE 2.952.758 y ISWC: T-042.653.562-7; preparo un estudio analítico al respecto.

45 En coherencia teórica con conferencias, así «Memoriae. Escucha y micro-calidades del sonido en la voz de Enrique Morente», y seminarios de composición que Sotelo suele impartir hasta la fecha.
} 
el punto de recordar con frecuencia una «verdad muy añeja», con puntos de encuentro respecto a la «asinidad positiva» de Bruno a nivel de acuidad; esto es, resulta más difícil aprender a escuchar que a cantar, según refirió antaño el cantaor, en su exilio o desierto interior de entonces, con motivo de la obtención del Premio Nacional de Música de 1994.

Sea como fuere, esta hermandad sinérgica o unidad estética cocreadora fue posible en una fructífera etapa del compositor en la que, al hilo de unos fragmentos para la ópera Bruno ..., tradujo, entre la cooperación concertada de cabales y el vuelo libre de un "pájaro solitario», la escritura poética, acuidad estética o música liminar de Valente en clave musical; eso sí, lo hizo bajo un luminoso y «ascendente» «Acorde» o «Sello solar», a modo de «columna estructural» del Teatro de la Memoria. Y es que procedió al calor del De Imaginum signorum et idearum compositione, Spaccio de la bestia trionfante y De l'infinito, conforme al ideal bruniano de «Natura est deus in rebus», porque «Oscuro es como la noche el canto», verso con el que arrancaba la ópera. Y el propio Morente, por su parte, acaso transitando de manera trascendente esta esfera mística que maridaba el pensamiento heterodoxo de Bruno y Valente, acabaría poniendo su voz magistral a ritmo de tangos, en calidad de «deseo abisal», a unos conocidos versos del Cantar del alma que se huelga de conocer a Dios por fe de San Juan de la Cruz, poeta predilecto en el imaginario tanto del poeta orensano como de Sotelo. Sirvan, pues, tales versos, con resonancias morentianas por añadidura y aprendiendo a «caminar soñando», al decir de Nono, como cadencia final para la intersección propuesta entre música y literatura a propósito de Valente en clave musical de Sotelo; porque como dijo el maestro granadino, estando en calidad de narrador-testigo el compositor, «La música se lee en el agua», al igual que «Oscuro es como la noche el canto»:

¿Qué bien sé yo la fonte que mana y corre, aunque es de noche!

\section{APÉNDICE TEXTUAL}

\subsection{CUADROS INICIALES DE BRUNO O EL TEATRO DE LA MEMORIA: VARIANTE REDACCIONAL PRIMIGENIA}

\section{CUADRO I}

Las tinieblas y la luz (Orco; Apolo)

(El escenario estará en sombra, cruzada sólo por ráfagas de luz tenue, como naciente. La primera -y más importante- voz debe oírse, pero no ha de verse al barítono. Estará en la zona de sombra.)

Primera voz:

Oscuro es como la noche el canto.

En el Orco no existe la memoria.

Ya no o todavía.

No pueden los muertos recordarnos.

Porque han bebido el agua de la fuente Leteo

y no podrían recordar lo viviente.

Resucitar es beber en las aguas

de Mnemosine,

la fuente de la luz que puede 
bajar segura a los dioses del fondo

hasta incendiar la sombra.

El Orco. [sic]

Musgo, humedad, arcillas, limo,

fenómenos del fondo,

de los barros oscuros

donde las figuras de los sueños se forman.

Sordas insignias de la sombra.

Animal que palpita.

Lo que palpita tiene

un ritmo y por el ritmo adviene,

recibe y da la vida.

En lo oscuro

el centro es húmedo y de fuego.

Madre, matriz, materia,

stabat matrix.

Rompe desde un sombrío abismo el sol.

Apolo,

el parto ardiente de la noche vino.

(Una iluminación lenta -o el levantamiento de un telón segundo- deja ver suavemente iluminado el cuerpo de Bruno maniatado al mástil de la hoguera).

Sigue la voz primera:

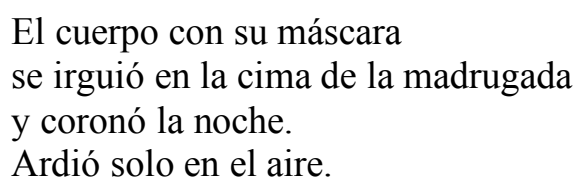

(Iluminación total, solar, de la hoguera).

Voz de Bruno:

Vuela, pájaro solitario en el abierto espacio venturoso,

renace en él, ya nada impide el vuelo,

el vuelo alto y ligero,

el amor con que ardes,

la simplicidad con que vas.

Ahora vuela y vuela y nunca tornes

a mí, porque ya no eres mío.

Primera voz:

El ojo,

como un extraño globo,

sube hacia lo infinito. 
(Queda un momento la cabeza de Bruno alzada, contra el madero, hacia los cielos del pájaro y se extingue despacio la luz).

\section{CUADRO III}

(Jove)

(Jove tiene un ademán majestuoso, pero desorientado y perplejo).

Jove:

La palabra que viene de lo oscuro

ha empezado a jugarnos sus múltiples propuestas.

Estamos aquí y no sabemos dónde estamos.

El hombre ha robado el fuego de los dioses,

un buitre devora eterno sus entrañas,

pero dolor y luz podrían a su vez aniquilarnos.

Un espasmo recorre la bóveda celeste.

Los dioses no nos fueron propicios.

Pero yo soy el dios, qué digo, el dios, los dioses.

Volvamos al comienzo.

Oigamos

las cóncavas palabras

del autor de esta obra.

(Interviene sin ser invitada Momos, la diosa del sarcasmo, hija de la noche. Podría llevar un gorro con cascabeles, como un bufón, pero ha de ser una mujer).

Momos:

Va a hablar mi maestro.

Cuánto sabe.

Mas ¿de qué le ha servido,

a no ser para huir acorralado

de París, de Ginebra,

de Oxford, de Alemania?

Ay, este fuego que tanto le devora.

Al final lo veo todo muy oscuro,

aunque sea para otros muy brillante.

(Mutis).

\section{CUADRO IV}

(Marte)

Bruno (a Jove):

Señor, este es el mapa.

No creáis

en el rigor del laberinto.

Jove:

Hace trescientos años que diseñaste el plan.

Hora es de ejecutarlo.

Aquí, en el centro

del Universo, 
vamos a efectuar la gran reforma.

Haz el viaje

y cuando llegues a su término

propiciarán la musa Erato y la Memoria,

la que a todas las musas ha engendrado,

el encuentro de Apolo con Diana.

Yo soy Jove, tu luz, tu entendimiento.

Bruno:

De nada sirve el entendimiento,

Señor, de nada sirve,

si no hay fortaleza.

Que venga Marte.

(Entra Marte, sólo reconocible por su casco, pero enteramente desarmado).

Bruno:

Dime, oh rey, ¿por qué apareces desarmado?

[Espacio en blanco amplio]

Marte:

No necesito portar armas.

Todo es cálculo y burocracia.

La guerra se prepara en los despachos,

en las fábricas y en la Bolsa.

Puedes contar conmigo en tu viaje.

Bruno:

Gracias te doy, rey Marte, mas necesito a Venus.

Pues ¿quién querría

habitar nuestro mundo sin su magia?

Jove:

Buscad a Venus.

6.2. ACTO I DE BRUNO O EL TEATRO DE LA MEMORIA: VARIANTE REDACCIONAL REVISADA

\section{ACTO I}

(1.) Las Tinieblas y la Luz

(Cori I, II e Orch.)

CORO (cantato):

Oscuro es como la noche el canto.

Porque han bebido el agua de la fuente Leteo,

ya no o todavía

podrían los muertos recordarnos.

En el Orco no existe la memoria.

Resucitar es beber en las aguas

de Mnemosine, 
la fuente de la luz que puede

bajar segura a los dioses del fondo

hasta incendiar la sombra.

$$
\text { El Orco. }
$$

Musgo, humedad, arcillas, limo,

fenómenos del fondo,

de los barros oscuros

donde las figuras de los sueños se forman.

Sordas insignias de la sombra ${ }^{46}$.

Animal que palpita.

Lo que palpita tiene

un ritmo y por el ritmo adviene,

recibe y da la vida.

En lo oscuro

el centro es húmedo y de fuego.

Madre, matriz, materia,

stabat matrix.

Rompe desde un sombrio abismo el sol.

Apolo,

el parto ardiente de la noche vino.

\section{(2.) Fulgor}

CORO (cont. $)^{47}$

El cuerpo con su máscara

se irguió en la cima de la madrugada

y coronó la noche.

Ardió solo en el aire.

\section{(3.) De L'infinito}

CORO (cantato).

Ahora tenía ante sí lo posible abierto a lo posible y lo posible.

Pimandro, Corpus hermeticum, I.

(Cori e Orch.)

\section{(4.) Génesis}

\footnotetext{
${ }^{46}$ En una revisión ulterior por Sotelo puede leerse en el momento narrativo en el que Bruno se dirige a la hoguera: «Bruno es conducido a la hoguera. Tensión creciente. Iluminación lentísima».

${ }^{47}$ Con retoques posteriores por parte del compositor: «CORO DE LUZ (Coro femenino)».
} 
Génesis.

Los vastos campos de la luz.

La abierta luz a lo infinito encuentra

el filo oscuro de la sombra.

Nace de ambos el fuego.

Sonoro el fuego

como un gemido ardiente.

Fulgor: el Verbo, la Palabra.

(5.) Venus [Diana tachado y escrito de nuevo]

(Sop., Coro femm., piano, perc., electr.)

VENUS (cantato). [DIANA tachado]

Deja que llegue a ti lo que no tiene nombre: lo que es raiz y no ha advenido al aire: el flujo de lo oscuro que sube en oleadas: el vagido brutal de lo que yace y pugna hacia lo alto: donde a su vez será disuelto en la última forma de las formas: invertida raíz: la llama.

(6.) Fulgor [Fulgor tachado y escrito de nuevo]

(Cori e Orch.)

CORO (cantato).

Y todo lo que existe en esta hora

de absoluto fulgor

se abrasa, arde

contigo, cuerpo,

en la incendiada boca de la noche.

(7.) Diana [Diana tachado y escrito de nuevo]

(Sop., Coro femm., piano, perc., electr.)

DIANA (cantato).

Tocaste las aguas, la quietud de las aguas, y engendraste la vibración: creciste en círculos: descendiste a los limos: penetraste en la noche y en la viscosidad creció lo múltiple: raíz de engendramiento: tú eres y no eres inmortal.

(8.) Mem [Mem tachado y escrito de nuevo]

(Basso, Cori) [Sop. I, II, Coro femm., Orch. tachado] 
... el que espera entrar en el nombre ha de velar nocturno a las orillas de la sola quietud: las aguas.

(9.) Tamquam centrum circuli (Morente, Cori, Orch.)

VOZ INTERIOR (cantato).

(Cori e Orch.)

La Memoria nos abre luminosos

corredores de sombra.

Bajamos lentos por su lenta luz

hasta la entraña de la noche.

El rayo de tiniebla.

Descendi, hasta su centro,

puse mi planta en un lugar en donde

penetrar no se puede

si se quiere el retorno.

Se oye tan sólo una infinita escucha.

Bajé desde mí mismo

hasta tu centro, dios, hasta tu rostro

que nadie puede ver y sólo

en esta cegadora, en esta oscura

explosión de la luz se manifiesta.

\subsection{IGNACIO GÓMEZ DE LIAÑO: EL TEATRO DE LA MEMORIA}

Sus andanzas por Europa y su muerte en Roma, condenado por la Inquisición a la hoguera, hicieron de Giordano Bruno (1548-1600) un símbolo. En los siglos XVII y XVIII se vieron reflejados en él los que aspiraban a superar las guerras de religión y a abrir al pensamiento horizontes cada vez más libres y amplios. En el XIX Bruno fue reconocido como representante del progreso. Y ya en nuestro siglo, el idealismo y el materialismo lo reivindicaron como precursor. El carácter universalista del pensamiento bruniano facilitaba el juego de las identificaciones. Pero al transformarse en símbolo, Bruno sufrió un inevitable proceso de reducción. Al final, se le hizo decir lo que se quería que dijese. Y se olvidó, mientras tanto, algo que había sido capital en su vida y en su obra: el arte de la memoria o, para ser exactos, la transformación que Bruno llevó a ese arte hasta hacer de él un método simbólico de autorreformación psico-ética. Se trataba de servirse de la construcción mental de lugares e imágenes, en que se basa el ars memoriae, para llevar a cabo un proyecto «mágico» de «cultura del alma» que estuviese a la altura de los tiempos. El Teatro de la Memoria de Giulio Camillo tuvo así en Giordano Bruno su desarrollo más cabal. El interés de [que tachado] este por los simbolismos como constituyentes del ser del hombre hizo de Bruno, aún más que un filósofo moderno, nuestro contemporáneo. La filosofía moderna, atareada como estaba en la investigación de la Naturaleza, se desentendió de esa vía central y, por eso, sólo pudo comprender a medias al filósofo italiano. Es en esa vía central de la cultura donde hemos querido volver a situar a Bruno.

Del Teatro de la Memoria hemos hecho Ópera, esto es, obra de arte total, acordándonos de lo que Bruno proclamó en uno de sus principales tratados mnemónicos (De Imaginum signorum et idearum compositione): «Hay un admirable parentesco entre los verdaderos poetas - 
a los que se asimilan los músicos-, los verdaderos pintores y los verdaderos filósofos; pues la verdadera filosofía es tanto música o poesía como pintura; la verdadera pintura es tanto música como filosofía; la verdadera poesía -o música - es tanto pintura como cierta divina sabiduría».

El Teatro de la Memoria describe un itinerario mágico en tres actos. Bruno, acompañado de Momo, es el peregrino.

Primer Acto.- La obertura muestra al nocturno Caos que, al fin, es igual cosa que el solar Apolo. Bruno, al que vemos en la hoguera de su transformación, aparece como el filósofo de la harmonía de los contrarios, de la coincidencia de los opuestos. Luego, en Saturno (primer peldaño de su descensus ad Inferos), el filósofo enseña a un grupo de discípulos el Mapa del viaje que se dispone a efectuar por los orbes celestes, lugares mágicos de su Memoria. Un artificio escenográfico situará en cada momento al espectador en un locus preciso dentro del MapaDiagrama: este se basa en el Siete (Primer Acto), el Doce (Segundo Acto) y el Diez-Cinco-Uno (Tercer Acto). Al llegar Bruno a la esfera de Júpiter, el viaje aparece en clave de «reforma de los cielos» (cf. Spaccio de la bestia trionfante); las constelaciones reflejan la condición moral del hombre. Descendiendo un peldaño más por la Hebdómada, Bruno llega a Marte, símbolo de la Fortaleza, y luego a Venus. La belleza de la diosa le deja sin habla. Pero ahí está Mercurio, el dios de la Palabra, que precede a la palabra suprema de Apolo y Diana. En ese momento se descubre el dramático amor del «furioso heroico»; el humorístico Momo lo declara sin recato, Diana y Apolo someten al visionario peregrino a una dura prueba, antes de descender a la Tierra, lo que es igual cosa que ascender a lo más alto del Cielo. El Peregrino ha de lidiar con los monstruos del Zodíaco.

Segundo Acto.- Acompañado de su inseparable Momo, Bruno se enfrenta a extrañas aventuras. La primera (Aries) se inspira en la del Vellocino de Oro, la segunda (Tauro) en el Laberinto de Creta, la tercera (Géminis) en el banquete legendario en el que Simónides descubrió las reglas del arte de la memoria. Cada Signo representa un valor simbólico dramatizado. El conjunto es la Odisea en el espacio del filósofo. El Acto termina en un banquete cuyo plato principal es el Pez de Piscis (penúltima constelación del Zodíaco). Con Acuario como acólito el Centauro Quirón oficia de sacerdote en el festín.

Tercer Acto.- Bruno aparece dormido en una playa, igual que Odiseo al llegar a Ítaca. Sale el Coro de las Musas. La Madre de estas, Mnemosine (asimilada a Diana y Erato, Musa de la poesía amorosa), anuncia los premios que se le tienen reservados. Cada Musa da a Bruno su don. Estamos en el círculo central del Mapa-Diagrama. Bruno se halla en lo más alto del Cielo, que es también el fondo de la Tierra. Presenciamos momentos de su vida en Italia, en Francia, en [enm. ope ingenii: el] Inglaterra, en Alemania. Los Símbolos se hacen Vida. Al fin, cuando el Mapa-Diagrama queda completado, aparecen, para coronar al poeta-filósofo, la doble pareja de Júpiter-Mnemósine y de Apolo-Diana. Momo ha hecho su última proeza. Sale a escena con Caos, al que trae atado. Todos se ríen de la cómica situación, pero le ordenan que suelte a su cautivo para que también Caos, junto a Momo, comparta la fiesta de la apoteosis. Bruno, en medio de la intensa luz, consigue, al colmar el Mapa de la Memoria, la anhelada Plenitud de la Vida.

Ignacio Gómez de Liaño

\section{REFERENCIAS BIBLIOGRÁFICAS}

Aguirre, Guillermo. 2014. «Fundamentos estéticos en el poema de José Ángel Valente, "El arte pobre"». Ogigia, 16: 17-31.

—. 2016. «Forma y abstracción en la poesía de José Ángel Valente». Rilce, 32.1: 5-31.

Besada, José Luis y Ordóñez Eslava, Pedro. 2019. «¿Una historia de la música espectral española? Transferencias culturales transnacionales en el último cambio de siglo». Acta Musicologica, 91.2: 168-189.

Bruno, Giordano. 1987. Expulsión de la bestia triunfante, trad. e intr. Ignacio Gómez de Liaño. Madrid: Alfaguara.

—. 1989; reed.: 1995. Expulsión de la bestia triunfante, trad. e intr. Miguel Á. Granada. Madrid: Alianza Editorial. 
—. 1993. Del infinito: el universo y los mundos. trad. e intr. Miguel Á. Granada. Madrid: Alianza.

Campos, Jorge. 2017. «Gerard Grisey y la música espectral». Colloquia. Revista de pensamiento y cultura, 4: 66-101.

Carreira, Xoán Manuel. 2016. «El público. Ópera bajo la arena de Mauricio Sotelo». En Teatro y música en los inicios del siglo XXI, coords. José Romera Castillo, Francisco Gutiérrez Carbajo y Raquel García Pascual. Madrid: Verbum, pp. 404418.

Díaz Gamboa, Sandra Lucía. 2009. La experiencia de los límites en la obra de José Ángel Valente y sus implicaciones lógico-matemáticas. Tesis doctoral. Madrid: UNED.

Escobar, Francisco. J. 2012a. «Sobre Valente y lo jondo: notas de poética». Studi Ispanici, 37: 293-315.

—. 2012b. «Tres lecciones de tinieblas, de José Ángel Valente: naturaleza musical, claves de poética e implicaciones simbólicas». Enthymema, 6: 118-191.

—. 2012c. «Pervivencia de Wozzeck, de Alban Berg en "Invención sobre un perpetuum

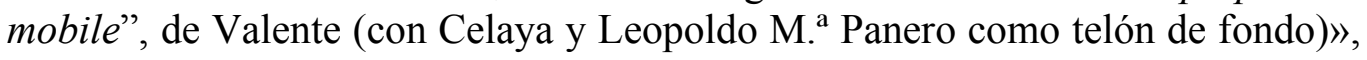
Il Confronto letterario. 57.1: 101-134.

—. 2012d. «Nueve cartas inéditas de José Ángel Valente a Concha Lagos (con Vicente Aleixandre y Dámaso Alonso al fondo)». Revista de Filología, 30: 185-200.

—. 2013. «Poesía y canción: El río sumergido de José Ángel Valente: cuestiones textuales, naturaleza genérica y fuentes». Demófilo, 45: 11-40.

—. 2017. «Valente interpreta a Schönberg: metamorfosis y avatares de un mito para una ópera de personaje». Degrés, 169-170.

—. 2019. «Y llevarte dormida a un jardín de coral: Representación de lo femenino, violencia y compromiso social en Valente (con redoble ritual de tambor afrocubano)». Revista de Estudios de género La Ventana, 49: 45-75.

Dufourt, Hugues. 2014. La musique spectrale. Une révolution épistémologique. París: Éditions Delatour.

Fernández Quesada, Nuria. 2000. «José Ángel Valente: “Siempre he sido absolutamente sensible al mundo circundante"». En Anatomía de la palabra, ed. Nuria Fernández Quesada. Valencia: Pre-textos, pp. 131-149.

Gan Quesada, Germán. 2008. Mauricio Sotelo. Música extremada, XXIV Festival de Música de Canarias. Las Palmas de Gran Canarias: Festival de Música de Canarias, pp. 308-347.

García Calero, Jesús (18-07-2001). «Mauricio Sotelo: "La poesía de Valente se me reveló como un espacio absolutamente musical"». Entrevista en $A B C$.

Gutiérrez Quesada, Balbino. 1996. Enrique Morente. La voz libre. Madrid: SGAE.

Lai, Antonio. 2008. «La imagen del sonido y la escritura espectral». Escritura e imagen, 4: $125-146$.

Martínez González, Francisco J. 2008. El pensamiento musical de María Zambrano. Granada: Editorial de la Universidad.

Ordóñez Eslava, Pedro. 2011. La creación musical de Mauricio Sotelo y José María Sánchez-Verdú: convergencia interdisciplinar a comienzos del siglo XXI. Tesis doctoral. Granada: Editorial de la Universidad.

Ordóñez Eslava, Pedro. 2019a. «Elogio de la apropiación. Prácticas impuras, flamenco y creación contemporánea». Cuadernos de música iberoamericana, 32: 95-114.

Ordóñez Eslava, Pedro. 2019b. «Lorca Unchained. Mauricio Sotelo’s El Público and the (new) Spanish Contemporary Opera», Contemporary Music Review, 38.1-2: 7693. 
Pérez Castillo, Belén. 1999-2001. «Sotelo Cancino, Mauricio». En Emilio Casares (dir.). Diccionario de la Música Española e Hispanoamericana VII. Madrid: Sociedad General de Autores y Editores, pp. 36-39.

Pérez Frutos, Iluminada. 2007-2008. «Tratamiento de la voz. Tradición oral en la obra de Mauricio Sotelo». Papeles del festival de música española de Cádiz. 3: 139-160.

Ramos, Diego. 2012. «Partiels, de G. Grisey. Percepción y estructura en la música espectral. Tratamiento específico de la escritura para cuerda». Espacio sonoro, 27: $1-94$.

Raposo Martín, Juan J. 2009. Luigi Nono: Epitafios Lorquianos. Estudio musicológico y analitico. Huelva: Hergué.

Saiber, Arielle. 2005. Giordano Bruno and the Geometry of Language. Aldershot: Ashgate.

Sotelo, Mauricio. 1995. Su un oceano di scampanellii per piano forte solo (1994/1995). Viena / Londres / Nueva York: Universal Edition.

—. 1997. «Luigi Nono o 'El dominio de los infiniti possibili'». Quodlibet, 7: 22-31.

-. 2001. «Memoriae». Cuadernos de la Huerta de San Vicente, 1: 53-63.

—. 2002. De magia per saxofono, percussione e piano forte (1995). Viena / Londres / Nueva York: Universal Edition.

—. 2003a. Si después de morir ... In memoriam José Ángel Valente. Madrid: Círculo de Lectores.

—. 2003b. «La dimensión musical en la obra de Eduardo Chillida». En Marisa Oropesa (ed.). Chillida. Música Callada. Madrid: Katalog zur Austellung des Hermitage Museums St. Petersburg, pp. 24-33.

—. 2003c. Si después de morir... für Stimme (Cantaor oder Alt), Flöte, Tonträger und Orchester (1999-2000) nach dem Gedicht Elegía: Fragmento (1994) von José Ángel Valente. Viena / Londres / Nueva York: Universal Edition.

—. 2007. Como llora el viento ... per chitarra ed orchestra (2007). Viena / Londres / Nueva York: Universal Edition.

—. 2008. Como llora el agua ... para guitarra (2007). Viena / Londres / Nueva York: Universal Edition.

Valente, José Ángel. 1997. Notas de un simulador. Madrid: Ediciones La Palma.

—. 2006. Obra completa. I. Poesía y prosa, ed. Andrés Sánchez Robayna. Barcelona: Galaxia Gutenberg / Círculo de Lectores.

—. 2008. Obras completas II. Ensayos. Ed. Andrés Sánchez Robayna; introd. y recop. Claudio Rodríguez Fer. Barcelona: Galaxia Gutenberg / Círculo de Lectores.

—. 2011. Diario anónimo (1959-2000), ed. Andrés Sánchez Robayna. Barcelona: Galaxia Gutemberg.

VV. AA. 2011. El canon. Revista de arte flamenco, 3.

Zambrano, María. «Entre el ver y el escuchar». Educación, 30 (1970): 112-113.

—. 1995. Un descenso a los infiernos. Toledo: Instituto de Bachillerato «La Sisla». 